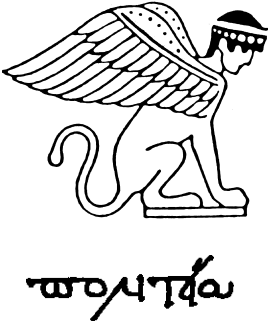

\title{
Ju.Everett, E.Redžić SEEKING REPRESENTATION: THE DEVELOPMENT OF HUNGARIAN MINORITY PARTIES IN SERBIA AND SLOVAKIA
}

Judas Everett - Ph.D. Candidate at the School of Politics and Governance, Faculty of Social Sciences, HSE University. Email: judas.everett@gmail.com.

Ena Redžić - Ph.D. Candidate at the School of Politics and Governance, Faculty of Social Sciences, HSE University. Email: enaredzic1@gmail.com.

Abstract. Ever since the 1920 Treaty of Trianon there have been sizable Hungarian minorities found in countries neighbouring the modern Hungarian state. Since the fall of authoritarian communist regimes and the rise of political plurality these minorities have sought representation, often through minority parties. This lens of political parties is applied in this article, in order to examine the seeking of representation by the Hungarian ethnic minority in Serbia and Slovakia. The overall development of parties is outlined, the stages of their development is illustrated and each stage is analysed in detail. The main findings are that Hungarian minority representation is incredibly fragmented and dogged by conflict in both countries, involving many splits in parties, with the formation and liquidation of parties common. However, during exceptional times they were able to show a united front to nationalist governments, this was observed in both Slovakia and Serbia. In more recent times conflict has returned to the fore, with the situations somewhat divergent. The high level of conflict within those seeking to offer political representation to the Hungarian minority in Serbia was notable, as was a lack of an end in sight. On the other hand, there were attempts to unite made in Slovakia, although they are yet to experience much success.

Keywords: Serbia, Slovakia, Hungarian minority, minority politics, party development, post-communist transition

Introduction

Minority rights and minority representation are topics for which straightforward, unproblematic and even unbiased solutions, strategies and answers remain incredibly elusive. As Jackson Preece noted "the „problem of minorities" has been a significant issue in international society for centuries. It has constituted an ongoing friction between states, a pretext for separatism, 
${ }^{1}$ Jackson-Preece 1997.

\section{Parties as a Lense of Minority Representation}

${ }^{2}$ Brubaker 2002.

${ }^{3}$ Pettai 2006.

${ }^{4}$ Brubaker 1995. irredentism and intervention, and a direct and indirect cause of local and general Wars" ${ }^{1}$. Indeed, sometimes these issues can ignite existing discontent and explode into violent confrontation. In other cases a simmering discontent stews below the surface, without ever bubbling over and becoming a stain on the history of the state. Some minorities have found themselves separated from their cultural and linguistic brethren by state boundaries, be that a separation from a dominant homogeneous group across a border, another minority group across a border, or in some cases both. Such cases offer a chance to contrast and compare the experiences of minority groups in different nation states.

The main research problem is the understudying of Hungarian minority representation by political parties in countries around Europe, especially at a time when most academia focuses on the increasing authoritarianism of the Hungarian government. Although there are links between the government in Budapest and many groups offering representation to Hungarian minorities in other countries, which undoubtedly affects and shapes these groups, this is beyond the scope of this article, which focuses on filling the considerable existing gap in understanding the parties offering representation. The main research question is who these parties are, what they represent and where they came from. Secondly, as they develop, how do they (re)position themselves in the multidimensional space parties occupy? In answering these questions their stages of development and the political context is also given consideration. Several patterns emerge: mostly that Hungarian minority representation is incredibly fragmented and dogged by conflict in both Slovakia and Serbia. However, notably, during exceptional times they were able to show a united front to nationalist governments. More recently conflict has returned to the fore, despite attempts to unite being made in Slovakia, especially.

The framework for approaching such a study must be decided and the first decision to be made is the referent object, here political parties have been chosen, despite the fact that many NGO, cultural or religious organisations could have been selected. Others do not lack importance or relevance; indeed, Brubaker suggests a broad array of non-traditional lenses to analyse ethnic and ethnic conflict ${ }^{2}$, and while this article chooses the more traditional lense of party presentation, it also acknowledges that other such lenses are legitimate and useful tools. The shortage of existing studies on parties makes this a logical choice for this article, but further exploration through other lenses is most certainly desirable.

When approaching the specific topic of Hungarian minorities in Slovakia and Serbia, it is important to be mindful of their position vis-à-vis Hungary and the state within which they reside and hold citizenship. The triadic relational nexus between national minority, nationalizing state, and external national homeland, in this case between Hungarians, Hungary and Slovakia/ Serbia, is a phenomenon noted by both Pettai ${ }^{3}$ and, specifically in this case, Brubaker ${ }^{4}$. The external national homeland, in this case Hungary, has been 
and Goldgeier 2004.

${ }^{6}$ Jenne 2004.

${ }^{7}$ Tarrow 2010.

${ }^{8}$ Lijphart 1971.

${ }^{9}$ Gerring 2006.

${ }^{10}$ Székely and Horváth 2014.

${ }^{11}$ Email Interview with Zoltán Szmieskó, the Chairman of MEP, by E. Redžić (2019). In Serbia the support flows through the foundation

Prosperati but also through other channels, Szmieskó stated.

noted to be employing a non traditional strategy ${ }^{5}$. External support has been found to be more important in explaining the demands and level of assertiveness displayed by minorities than how much respect their rights really receive ${ }^{6}$. The increasingly assertive nature of the external national homeland, although through non traditional strategies, is a major factor in why such a study is currently especially salient.

Turning now to the case selection, the role of the strategy of paired comparison was discussed by Tarrow, who attempted to theorise and practically improve the use of paired comparison ${ }^{7}$. The cases selected here are done so on the basis of most-similar systems design, famously outlined by Lijphart ${ }^{8}$, and later, among others, Gerring who noted the advantages of this approach'. The Hungarian minorities in Slovakia and Serbia allow the study of two groups which are cultural and linguistically very similar, if not identical, in two countries which are close in terms of geography but have experienced some differences in their post-communist transitions. The differences which are likely to be enhanced by this approach are differences in party organisation and, as noted by Székely and Horváth, the attitude of states toward diversity recognition and registration ${ }^{10}$.

Despite some differences in their post-communist experiences, Serbia and Slovakia have been chosen to be focused on due to their striking similarity, particularly in the case of the experiences of their Hungarian minority parties. In both Serbia and Slovakia minority parties based on Hungarian identity have been formed and compete in elections. In neither Serbia nor Slovakia has the Hungarian minority's search for representation been confined to a single party. In order to answer the research questions, the political parties offering representation specifically to the Hungarian minority in Serbia and Slovakia will be mapped, offering a better understanding of the political landscape within which they operate, especially while the support for Hungarian minority parties from Budapest has never been bigger than during Fidesz in power, an important part of the triadic relational nexus ${ }^{11}$. In terms of structure, firstly, a summary of party development is provided, before focusing on the stages of party development, namely: party roots and early years, opposition to nationalist governments and finally entering the mainstream but still dogged by conflict.

Summary of Party Development
The stages or development in the parties which offered representation specifically to the Hungarian minority in both Slovakia and Serbia were remarkably similar in their stages of development. Initial emergence was followed by opposition to highly nationalist governments and finally an entering of the mainstream (of sorts). However, even having entered the mainstream, internal and intergroup conflict is still characteristic of the experience of Hungarian minority parties in both countries.

The development of Hungarian minority parties in Slovakia can be split into three distinct stages: firstly, the emergence of parties as the communist regime collapsed; secondly in opposition to the Mečiar government; then thirdly, 
${ }^{12}$ Sasse 2005.

${ }^{13}$ Millard 2004.

${ }^{14}$ For a detailed picture see Székely 2014.

\footnotetext{
${ }^{15}$ Official languages in Vojvodina are: Serbian, Hungarian, Slovak, Romanian, Croatian and Pannonian Rusyn.
}

entering the mainstream. Initially, four Hungarian parties emerged, illustrating that the Hungarian minority did not represent a unified political force ${ }^{12}$. However, parties in the early stages often formed coalitions, showing that they were at least willing to work together when politically expedient. Then a merger of MPP, MKDM and EPM (a) occurred in 1994.

The 1998 merger of Hungarian minority parties was caused by the raising of vote thresholds which required each party in a coalition to receive at least $5 \%$ of the vote, as a result the Slovak Democratic Coalition and the Hungarian parties registered as single parties ${ }^{13}$. While this rule change could have potentially been incredibly damaging for the Hungarian minority parties, the opposite was the case. Three parties (MPP, MKDM and EPM) had already been in coalition together and in uniting with MNP under one party banner the Hungarian minority was united, as a political force in Slovakia, for the first time (b). The raising of the threshold also coincided with the Hungarian minority party's move from opposition into government and the mainstream. The Party of the Hungarian Coalition (c) operated under this name until 2012 (d) when they rebranded as the Party of the Hungarian Community (e) (SMK-MKP), this followed both Béla Bugár leaving to form the Most-Híd party $(f)$, and some disappointing electoral results under the old name. Most-Híd have continued to represent the Hungarian minority in the mainstream, although they also aim to attract Slovak voters, the fate of The Party of the Hungarian Community (SMK-MKP) remains unclear but they appear to have found themselves in the political wilderness.

In Serbia, parties experienced the same initial phase after the socialist regime collapse, while even in the second phase the polarisation of parties was notable through splits and the rise of the new parties. Lastly, the consolidation of smaller organisations with larger parties and coalitions of Hungarian parties. The Alliance of Vojvodina Hungarians (VMSZ - Vajdasági Magyar Szövetség) (a) as the biggest party has been the only consistent parliamentary party representing Hungarians in Serbia. Apart from the splits and mergers occurring throughout the 1990s and 2000s (d, c, f, g, h), creation of the new parties, mainly from moderate and radical right interested in some type of autonomy ${ }^{14}(i, j)$, VMSZ, Democratic Community of Vojvodina Hungarians (VMDK, Vajdasági Magyarok Demokrata Közössége), and Democratic Party of Hungarians in Vojvodina (VMDP - Vajdasági Magyar Demokrata Párt) (e) are the only parties that survived all three periods identified in this study.

Presently, Hungarians have an absolute majority in 6 and a relative majority in two municipalities in the north of Vojvodina and the Hungarian language is one of the official 6 languages ${ }^{15}$ in the province. Hungarian National Council (HNC) is one of 20 minority councils which are funded from the national, provincial and local budgets for the purpose of the exercise of the rights to self-government in culture, education, information and official use of languages and scripts. The HNC has been presided over by VMSZ prominent party members. Hungarians are the second largest ethnic 
group in Vojvodina with $13 \%$, and in the Republic of Serbia with $3.53 \%$ of

${ }^{16}$ Census 2011. the population share in the 2011 population census ${ }^{16}$. Despite being the largest minority group, the Hungarian ethnic group has experienced a decrease in population with each population census. As such, they are the ethnic minority with the largest decrease in population in Serbia, reportedly caused mainly by the ability to hold double citizenship whereby many young Serbian Hungarians emigrate to Hungary for better working opportunities and

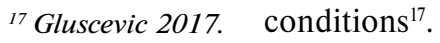

\section{Figure 1 Scheme of the Development of Hungarian Minority Parties in Slovakia}

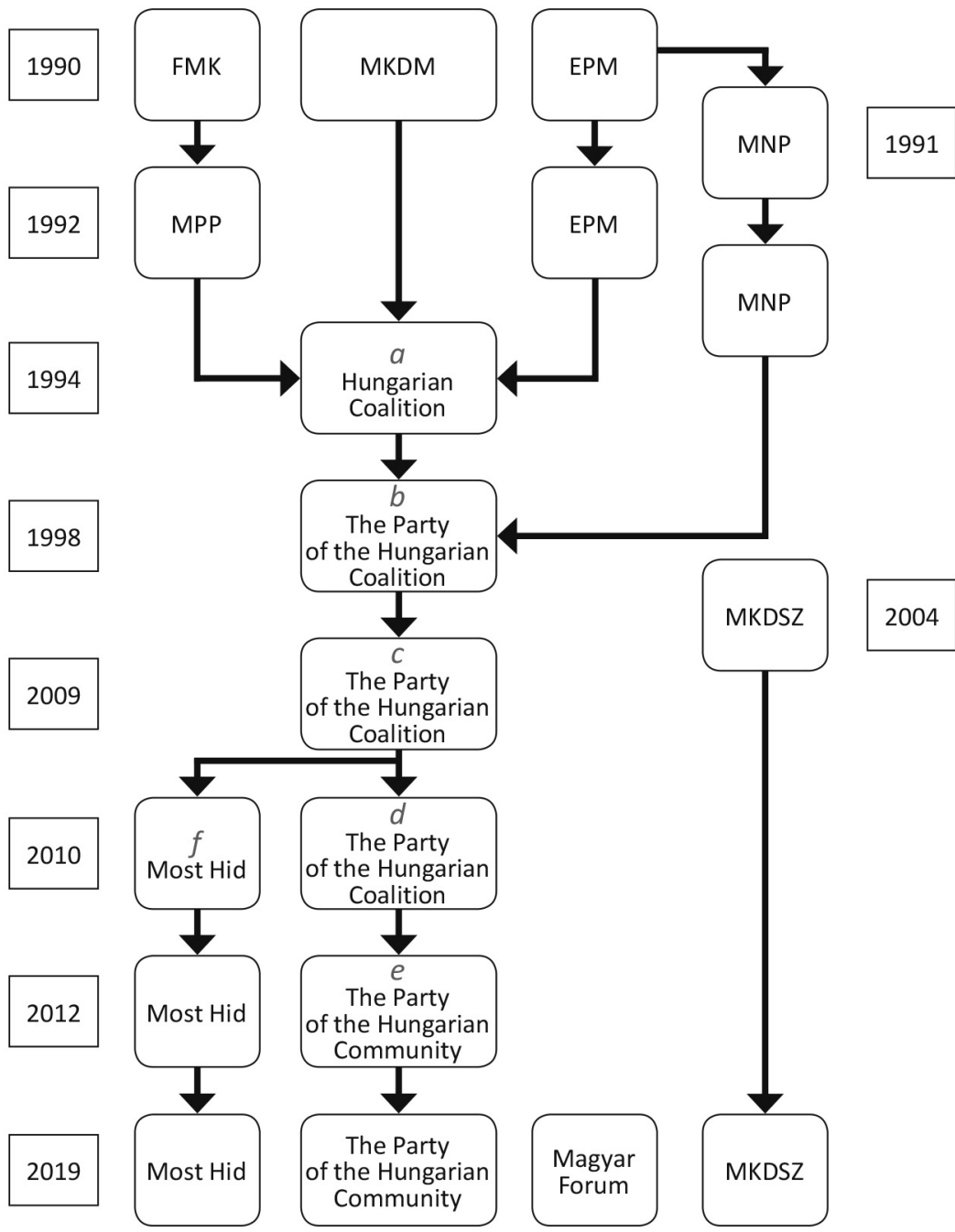


Figure 2 Scheme of the Development of Hungarian Minority Parties in Serbia

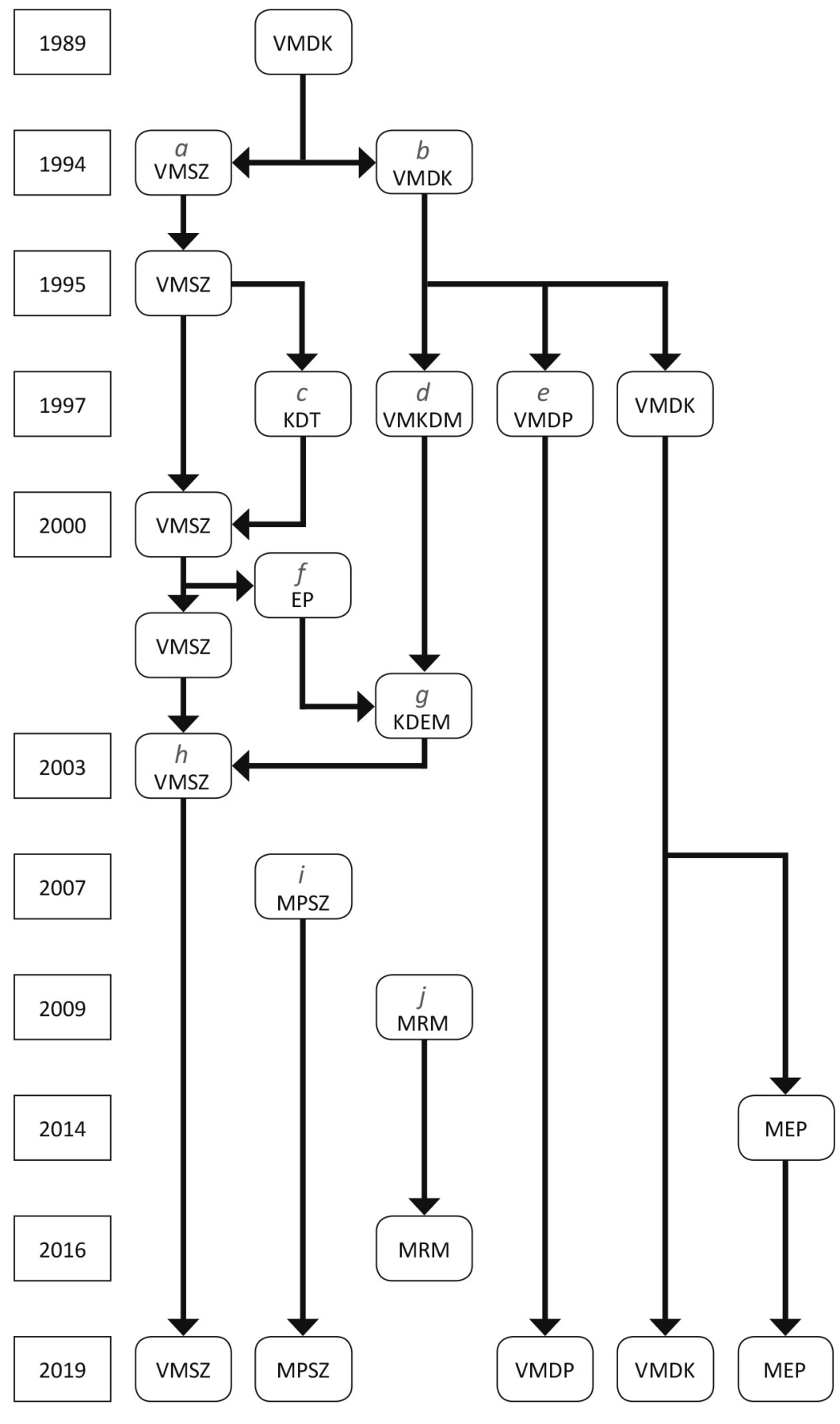




\section{Party Roots and Early Years}

${ }^{18}$ Sasse 2005.

${ }^{19}$ Bolton 2012.

${ }^{20}$ Howe, Sontag, and Vonnegut 1983.

${ }^{21}$ Vagovič 2009.

${ }^{22}$ Rosenberger 1993.

${ }^{23}$ Sulavik 1992.

${ }^{24}$ Šimečka 2020.
Political parties are not born out of vacuums. Despite the communist governments of Yugoslavia and Czechoslovakia limiting the activities of civil society and ideologically seeing, or at least claiming to see, the divisions among people as class based rather than ethnically or linguistically based, these minority parties were not born out of a vacuum either. This section first addresses the roots and development of parties in Slovakia before turning attention to the parties of Serbia.

Slovakia. As the communist regime collapsed and Slovakia became a transitioning state, four Hungarian parties emerged, this was only early in the transitional phase but it illustrated that the Hungarian minority did not represent a unified political force ${ }^{18}$. Where did these four parties originate from? In Czechoslovakia, one of the main opposition groups was the group which came to be known by the document they signed: Charter 77. Like almost all matters in Czechoslovakia even this was a Czech dominated affair, of the original 241 signatories, some 90 percent lived in Prague or a nearby suburb, with most of the rest in Brno ${ }^{19}$. Miklós Duray was a signatory of Charter 77 who was persecuted for his attempts to draw the outside world's attention to the plight of the Hungarian minority in Czechoslovakia ${ }^{20}$. Duray was also a co-founder of the Committee for the Protection of the Rights of Hungarians in Czechoslovakia and was imprisoned on several occasions ${ }^{21}$. Following the collapse of communism he continued to advocate for minority rights, even accusing the Slovak government of pursuing "velvet ethnic cleansing" 22 .

Despite never containing the numbers that, for example, Solidarity in Poland was able to boast, the opposition in Czechoslovakia was instrumental in the political awakening of many. As such, The Független Magyar Kezdeményezés (FMK, Independent Hungarian Initiative) movement was closely linked to the umbrella organisation of the Slovak democratic opposition, VPN (Public Against Violence), in 1992 FMK transformed into a political party, changing its name to Magyar Polgári Párt (MPP, Hungarian Civic Party).

One of the other few outlets of civil society, besides sources of political awakening such as the intellectually dominated Charter 77, was the church. Hungary, Poland and Slovakia had stronger religious tendencies than other countries in the region and it should come as no surprise that at least one party was borne out of a Catholic group of intellectuals. Others almost certainly had a Catholic membership but Magyar Kereszténydemokrata Mozgalom (MKDM, Hungarian Christian-Democratic Movement) grew out of a movement in 1990 of Catholic intellectuals attempting to reach rural voters and was quite explicit in its religiosity. Alongside this was the Magyar Kereszténydemokrata Szövetség (MKDSZ), a much less successful Christian organisation, founded later in 2004 by Csaba Feher, and continues to fight elections ${ }^{23}$. Béla Bugár was one of the central figures of MKDM and would continue to be a central figure for the Hungarian minority even as parties came and went ${ }^{24}$. Other parties found their roots not through academic activity, nor through dissident movements, nor through the church, but purely through a concern for minority rights. Együttélés Politikai Mozgalom (EPM, Coexistence Political

"ПONMTIS" № 2 (101) 2021 
${ }^{25}$ Bugajski 2002.

${ }^{26}$ At the beginning of the 1990s, VMDK did not consider itself a political party, but rather a political organisation that fulfilled certain party functions (see Hódi 1992).

${ }^{27}$ Bárdi 2004.

${ }^{28}$ Hódi 1997.

${ }^{29}$ Petsinis 2020.

${ }^{30}$ Mirnics 2000.
Movement) was formed in 1990 and was initially intended to represent all of the minorities of Slovakia. As such within its membership it was possible to find Ruthenian and Polish minorities as well as Hungarians. However, following Slovakia's independence in 1993 it became an exclusively Hungarian party. A splinter group from EMP went on to form Magyar Néppárt (MNP, Hungarian People's Party) in the summer of 1991, although they were joined by some former MKDM members they experienced limited success before merging with other parties in $1998^{25}$.

Serbia. The end of the 1980s and the beginning of the 1990s were a dark period in South-Eastern Europe due to vicious conflicts between the former Yugoslav republics. The nationalist programme of the first Serbian president Slobodan Milosevic limited the autonomy of Vojvodina and formally reincluded the territory in the Serbian territorial border. In the beginning of the 1990 s, the one-party system was formally abolished which led to the creation of various ethno-political organisations among which there was one dedicated to Hungarian minority representation. Following the events which occurred on the territory of the former Yugoslavian republics, the Hungarian minority in Serbia gathered around an ethnic organisation for the first time, one led by András Ágoston, a former trade leader and a prominent figure in the Hungarian community. The VMDK formed in 1989, advocated for minority rights, multiparty elections and the democratisation process in Serbia, also strongly supporting the transition to a market-economy.

While in Slovakia the post-communist political mobilisation resulted in the creation of several Hungarian organisations, in Serbia, the Hungarian minority was characterised by uniform support for VMDK. In 1992, the organisation $^{26}$ reached over 20,000 members, soon calling for a stronger relationship between Hungarians and the autonomy of Hungarians in Vojvodina, refusing to collaborate with any Serbian politicians. VDMK was politically and financially isolated from Serbian political and public life. Unwilling to cooperate with local players, VMDK leaders sought funding from the international community and Hungarian government organisations. Until 1994, VMDK was receiving significant financial aid from the Hungarian center when the Budapest center-left coalition decided to support the more moderate and electorally legitimate $\mathrm{VMSZ}^{27}$. In 1994, a financial scandal leading to a first split among Hungarian political representatives revealed the existence of several factions inside VMDK. The centre of the party was caught between radicals, who aspired towards potentially violent secession, and pragmatists, who expressed the need for increased cooperation and better relations with the existing Serbian parties $^{28}$. Another factor behind the split were allegations of increased intraparty authoritarianism within the ranks of VMDK ${ }^{29}$.

As a result of VMDK's financial scandal Sándor Hódi, VMDK vice president, refused to report his financial activities to the party leadership ${ }^{30}$, the internal conflict reached its peak at the March 1994 VMDK general assembly meeting. The organisation's center held Hódi liable for the potential mishandling of funds, since he was the chairman of the foundation which received 
financial assistance from the Hungarian government and distributed it to the VMDK. On the other side was a faction led by Ferenc Czubela who became the leader of the newly formed VMSZ. Members of the newly formed VMSZ left VMDK because their attempts to allow space for different ideologies with-

${ }^{31}$ Ibidem. in VMDK failed ${ }^{31}$. Both organisations registered as political parties, VMDK in March and VMSZ in June $1995^{32}$.

After the creation of VMSZ, a series of events weakened Ágoston's VMDK: three of five national, one of three federal assembly MPs and most

${ }^{33}$ Székely 2014. of Vojvodina assembly representatives (13 of 17) defected to VMSZ ${ }^{33}$. Furthermore, the center left coalition in Budapest chose to support the more liberal

${ }^{34}$ Bárdi 2004. VMSZ ${ }^{34}$. The 1996 elections resulted in the final defeat of VMDK by VMSZ, winning three seats in the national assembly, to VMDK's zero, 13 provincial

${ }^{35}$ Vékás 1998. (one for VMDK) and 130 seats at municipal level ${ }^{35}$.

In 1997, VMDK suffered from factional divisions once more, however this time the Ágoston-led faction left the party and formed VMDP. The conflict between factions began due to discussions over a potential coalition with VMSZ where the vice president of the party, Sándor Páll disobeyed the general assembly's rejection of the coalition. Later, even after being expelled from

${ }^{36}$ Ibidem. VMDK $^{36}$, Pall called for a general assembly meeting, dismissed the central leadership, and annulled all the changes made to the organisation statute after $1990^{37}$. Lastly, the new VMDK leadership declared their willingness to cooperate with other Hungarian minority parties (especially VMSZ) and Serbian parties of the democratic opposition in the end of 1990s. The three factions which originated from the 1990 VMDK played primary roles in 1990s Hungarian minority politics. VMSZ as the obvious favorite won many battles with its pragmatic approach and openness to cooperation with Serbian parties as well as the absolute support of Budapest, the external national homeland part of the triadic relational nexus.

Opposition to Nationalist Governments

${ }^{38}$ Horowitz 1993.

${ }^{39}$ Goldman 1999; Deegan-Krause 2012.
There is naturally some overlap between the formation of parties, their early years and the period in which they opposed nationalist governments. The most notable feature of this period, perhaps the thing which makes it distinctive, is that they showed significant capacity for compromise and working with others. Ethnic parties have been shown to compromise when they have strong political incentives to do $\mathrm{so}^{38}$, which is definitely the case here. Moreover, this is an important phase of development for Hungarian minority parties, notably one which exists in the development arc of Hungarian minority parties in both the Slovakian and Serbian cases. While Slovakia never came close to armed conflict, research at the time reflected a transition to democracy in Slovakia which was far from flawless ${ }^{39}$.

Slovakia. While Mečiar was in power (June 1992-March 1994 and October 1994-September 1998), the Hungarian parties achieved very little. When Mečiar's opponents were governing, the Hungarian parties gained more of a meaningful voice either as government supporters, from March to October

"ПONTIIT" № 2 (101) 2021 
${ }^{40}$ Millard 2004. 1994, or as part of formal coalitions, following $1998^{40}$. Even succeeding in having a Hungarian as deputy Prime Minister for human rights and minorities in

${ }^{41}$ Ibidem. the Dzurinda government ${ }^{41}$. Becoming a respectable coalition partner was in no small part due to the Hungarian parties' move away from initial demands for regional self-government towards an emphasis on decentralisation and local government. This narrowed the gap between the Hungarian parties and

${ }^{42}$ Sasse 2005. other members of the opposition ${ }^{42}$, representing movement towards integration on the continuum.

External pressures also helped to bolster the Hungarian parties and their causes as The Framework Convention for the Protection of National Minorities was a condition for EU membership and The Council of Europe's European Charter for Regional or Minority Languages (ECRML) both gave legitimacy to central causes of the Hungarian parties. In fact, Slovakia actually created a hierarchy of minority languages with Hungarian on top, followed by Ukranian and Ruthenian - this despite having conferred the status of regional or minority language to Bulgarian, Croatian, Czech, German, Hungarian,

${ }^{43}$ Ibidem. Polish, Roma, Ruthenian and Ukrainian ${ }^{43}$.

Serbia. Similarly, the Hungarian minority in Serbia found themselves on the periphery facing an extremely nationalist government. Moreover, following initial splits in Hung. minority political representation, a meaningful large-scale coalition capable of embracing all ideologies among Hungarians in Serbia was not forthcoming. VMSZ, the largest Hungarian political party in Serbia, consistently pursued improved relations with Serbian parties, this was accomplished by close collaboration and coalition with the democrats.

The most notable characteristic of Hungarian minority politics in Serbia is the amount of fragmentation. Between the mid-1990s and mid-2010s, several smaller parties registered for elections, but most of them failed to gain significant public attention. Most were small splinter factions which operated independently for a period of two-three years and later merged with VMSZ. In 1995, the only non-splinter party was formed under the name Hungarian Civic Movement of Vojvodina (VMPM - Vajdasági Magyar Polgári Mozgalom). The VMPM leaders declared their objectives of supporting the goal of the autonomy of Vojvodina province and in 2003 merged with VMSZ. Two minor parties, the Christian-Democratic Movement of Vojvodina Hungarians (VMKDM Vajdasági Magyarok Kereszténydemokrata Mozgalma) formed at the beginning of 1997, and Európa-Platform originated from the VMDK and the VMSZ respectively. They formed the Christian-Democratic Europe Movement (KDEM - Keresztény-Demokrata Európa Mozgalom) in 2003 and joined VMSZ soon after. In the same year the Christian-Democratic Alliance (KDT - Kereszténydemokrata Tömörülés) was registered in the Senta municipality and followed the party agenda of the former vice-president of

${ }^{44}$ Székely 2014. VMDK, Sándor Hódi ${ }^{4}$.

When Democratic Opposition of Serbia (DOS, Demokratska opozicija Srbije) was created as an alliance of parties to overthrow Slobodan Milošević and his Socialist Party. After winning the General elections in 2000, until 
${ }^{45}$ Ibidem.

the murder of the Prime Minister Zoran Đinđić in 2003, several parties left DOS, but VMSZ remained. The other two Hungarian parties didn't experience large-scale collaboration with Serbian parties, but rather remained indifferent to the internal politics of Serbia. VMSZ closely collaborated with the Democratic Party led by Boris Tadic, which was a result of the close cooperation with the Democratic Party (DS - Demokratska stranka), particularly favoured by the leader of VMSZ, József Kassa ${ }^{45}$. However, in 2004 the number of VMSZ mandates at all levels decreased. Zuber assigned such a loss not to the activities of other Hungarian minority parties but to the higher "ethnic predating" activity of DS. They won a higher number of Hungarian ethnic votes by fielding more ethnic Hungarian candidates in minority populated are-

${ }^{46}$ Zuber 2012. as ${ }^{46}$. In 2002, Vojvodina gained more rights after the large-scale support of ethnic minorities for the winning democratic block. In both Serbia and Slovakia, powerful, nationalist governments were seen off by large-scale big-tent cooperation which included minorities, minority parties and, most notably here, Hungarian minority parties.

Entering the Mainstream but Still Dogged by Conflict

${ }^{47}$ Most-Hid is bridge in the Slovak and Hungarian languages.
The groups offering representation to the Hungarian minority in Slovakia and Serbia were not only united by their time in opposition to nationalist governments, but also by their possibility to experience a more mainstream position having seen off this threat. However, as illustrated below, they were also united by their inability to truly take advantage of such an opportunity. The internal conflicts which exist within groups, often leading to splits and defections, is a huge barrier to offering any kind of stable representation. Moreover, the conflict between different Hungarian minority groups is striking in both its senselessness and its salience in preventing closer cooperation. While both countries clearly exhibit similar tendencies, the extent differs, with Serbia being much more severe in its fragmentation than Slovakia. Moreover, attempts to unite the Hungarian minority in Slovakia appear to have greater potential than in Serbia.

Slovakia. The Mečiar governments had been hostile to Hungarian minorities, but without this obstacle the Hungarian parties might have been expected to flourish. However, as in Serbia, infighting and internal conflict weakened Hungarian representation in Slovakia. Most-Híd was created by a separation from the previously biggest Hungarian minority party, the Party of the Hungarian Community, which could have created issues for the representation of the Hungarian minority in Slovakian parliament.

In 2009 Béla Bugár left to form the Most-Híd party and most of the party's voters followed him, this party represented a move towards integration on the continuum as it sought to represent both Hungarians and Slovakians $^{47}$. Most-Híd received 205,528 votes $(8.12 \%)$ and 14 seats. Meanwhile, the Party of the Hungarian Coalition received 109,638 votes (4.33\%) and no seats at all. The resignation of the party leadership was not enough to change the fortunes of the party and the results were similar in the 2012 election as 
${ }^{48}$ Details of the electoral results may be found at the Inter-Parliamentary Union website: http://archive. ipu.org/parline-e/ reports/2285_A.htm.

${ }^{49}$ Székely 2014.

${ }^{50}$ Haughton 2014.

${ }^{51}$ Most-Hid 2019.

${ }^{52}$ Magyar-Hungarian Forum Party 2019. the renamed Party of the Hungarian Community received 109,484 votes (4.28\%) and 0 seats yet again. Again similarly Béla Bugár's Most-Híd received 176,088 votes $(6.89 \%)$ and 13 seats. Finally, in 2016 the results confirmed the switch in Slovakian Hungarian minority politics had become entrenched as yet again Most-Híd outperformed the Party of the Hungarian Community, receiving 169,593 votes $(6.50 \%)$ and 11 seats to SMK-MKP's 105,495 votes $(4.05 \%)$ and 0 seats $^{48}$.

The split was not along the lines of the predecessor parties, which had merged as a result of the 1998 electoral law, instead it was ideological. The more radical, which also had closer connections to Hungary itself, and those better integrated into the Slovak polity could no longer continue to find midgrounds and compromises ${ }^{49}$. While Most-Hid sought better connections and more acceptable positions to Slovaks and The Party of the Hungarian Community (as it came to be named) continued in a similar vein, the results may well be disappointing for both ${ }^{50}$. The Party of the Hungarian Community has polled at around $4 \%$ in several elections and due to the $5 \%$ threshold have failed to gain any seats at all. Whether or not this represents a failing of the Slovak electoral system, as it leaves many without meaningful representation, or a barrier by design is unclear. There is little sign of either rule changes which would accommodate the party or increased electoral success. In the case of Most-Hid, their support has been higher than the aforementioned party, but they have still lost several seats over the course of three elections which may be something of a cause for concern. Having taken a more conciliatory position, a wider base of support and more votes may have been expected and this has not exactly come to pass.

Despite the issues which both parties have faced, as well as their rather consistent levels of support, the two parties have not been able to come to an agreement to stand together. Negotiations in 2019 resulted in the rejection of forming a single party or standing jointly on the Most-Hid slate; while the idea of a potential coalition continues to be discussed, a basic precondition for cooperation is said to be preserving the identities and basic principles of the parties $^{51}$. Therefore, it seems the electoral rules of Slovakia are a hindrance to the Hungarian minority parties there, but the protracted conflict between those seeking to offer representation to the Hungarian minority in Slovakia only serves to exacerbate matters further. This exacerbation takes the form of both the inability of the two biggest parties to work together in meaningful ways, but also in the founding of new parties, such as Magyar Forum in 201952. Most-Hid may enjoy the majority of support and electoral success, but the Hungarian minority parties in Slovakia continue to be dogged by conflict, although as will be outlined below, to a lesser extent than their Serbian counterparts.

Serbia. In contrast to the threshold problems which have dominated issues of electoral success, most often as a barrier to electoral success, in Slovakia, the Serbian experience is the opposite. The level of fragmentation and the number of groups offering representation to the Hungarian minority in Serbia are both considerably higher than in Slovakia. Székely argues the extreme 
${ }^{53}$ Székely 2014.

${ }^{54}$ Ibidem.

${ }^{55}$ Ibidem.

${ }^{56}$ Osnovana 2012.

${ }^{57}$ Székely argues that the ratio of Hungarian votes was spread between the VMSZ which won $80 \%$, and $V M D K$ and VMDP which both held $10 \%$ each (see Székely 2014).

${ }^{58}$ A Magyar Koalíció 2008.

${ }^{59}$ Only $V M D K$ and MPSZ candidates were on the list of All Together coalition.

Hungarian party fragmentation in Serbia was a result of the poor requirements for party registration and the abolishment of the threshold for the parliamentary elections prior to the 2007 elections $^{53}$.

In 2007, the Hungarian Civic Alliance (MPSZ - Magyar Polgári Szövetség) party, led by a former VMSZ politician, László Rácz Szabó, officially registered as a party. This party was the first official organisation with conservative, right-wing Hungarian national views. Rácz Szabó reportedly left VMSZ for moving too far to the left. The discourse of his MPSZ is centred on the values of the Holy Crown of the Kingdom of Hungary. Two years after the rise of the right-wing MPSZ, the most radical Hungarian minority organisation registered as the Hungarian Hope Movement (MRM - Magyar Remény Mozgalom) party ${ }^{54}$. The MRM leadership formed the party after they attempted to overthrow the local leadership of VMDP, their root party, in Subotica (Szabadka) municipality. Székely reports that MRM maintains a close relationship with the radical organisation Hatvannégy Vármegye Ifjúsági Mozgalom and party Jobbik Magyarorszagért Mozgalom ${ }^{55}$. In 2012, Zoltán Szmieskó, a former VMDK representative registered the Hungarian Unity Party (MEP - Magyar Egység Párt). He claimed the party's objective was to represent the around $40 \%$ of Hungarians who do not vote and those who vote but not for Hungarian parties ${ }^{56}$.

The first coalition between two Hungarian minority parties occurred during 2007 when VMDK and VDMP almost entered the national parliament. VMSZ won three seats which failed to meet expectations. Election results from 2007 indicated that the Hungarian minority would have won five seats in the national parliament if the MK coalition between VMDK and VMDP had also included the VMSZ ${ }^{57}$. In May 2007, István Pásztor became leader of the VMSZ and joined the VMDK coalition (VMDP) for the upcoming 2008 presidential, parliamentary, provincial, and local elections. The coalition between old rivals required the signing of the Hungarian Coalition Autonomy Concept, the agenda created for the pursuit of autonomy of Hungarians by all parties, but lasted only a few months ${ }^{58}$. Nevertheless, the presidential elections saw the peak in Hung. minority votes, as István Pásztor, the MK coalition candidate, won $2.3 \%$. Subsequently, parliamentary election results disappointed. VMSZ, as a representative of MK, also formed a coalition with DS on the provincial level. VMDK decided to leave the coalition soon after the formation of the government, while VMDP left due to the differences in approaching the law of minority national councils.

Prior to the parliamentary and provincial elections in 2012, the initiative to create a single united opposition to VMSZ was almost successfully implemented. The Hungarian minority parties joined the coalition "All Together" which was created as a platform for all minorities. However, most of the parties quickly left the coalition led by the Bosniak Democratic Union (BDU) ${ }^{59}$ which won one seat in the national parliament. MRM decided to participate in the provincial and local elections winning $0.59 \%$ in Vojvodina. Despite not entering the provincial assembly, MRM rose to be the second Hungarian minority party, after VMSZ. Zoran Secerov, the vice president of MRM stated that 
${ }^{60}$ Tanjug 2013. territorial autonomy is the key point in the party agenda ${ }^{60}$. In 2012, Jobbik leadership in Budapest officially supported MRM on the basis of joint objectives and protection of ethnic Hungarians in Vojvodina, "to whom Hungarian govern-

${ }^{61}$ Necin 2012. ment failed to provide the necessary support" ${ }^{\prime 1}$, changes in the situation of the external national homeland were clearly felt by the national minority in Serbia.

In 2015, the leader of the newly formed Hungarian Movement (MM Magyar Mozgalom) stressed the lack of focus on autonomy objectives within VMSZ as one of the main reasons for leaving and forming MM. Its coalition with VMDK and alignment with pro-autonomy parties, such as VMDK,

${ }^{62}$ Ifkovic 2015 . yielded two seats in the Vojvodina assembly ${ }^{62}$. All current parties, with the exception of VMSZ, represent more right-wing aspirations. In 2017, Istvan Pazstor called MM an extension of the radical MRM, which ceased to exist in 2016 and linked them to the far-right organisation Jobbik, which Varga

${ }^{63}$ Marjanov 2015.

${ }^{64}$ DZVM 2015.

${ }^{65}$ Three 2016.

${ }^{66}$ In Bečej and Novi Bečej municipalities.

${ }^{67}$ Email Interview with Zoltán Szmieskó, the Chairman of $M E P$, by E.Redžić (2019).

${ }^{68}$ Tanjug 2015.

${ }^{69}$ Ifković 2015.

70 Tumbas 2015. denied $^{63}$. On the other hand, the same year VMDK condemned the political practice of VMSZ. An official VMDK statement claims that VMSZ undermines the autonomy of Vojvodina through its support of the national budget, which did not fulfill the necessary $7 \%$ share to Vojvodina, while formally claiming that VMSZ is the only protector of the autonomy of the province ${ }^{64}$.

Prior to the 2016 elections, VMSZ, MEP and VMDP created a coalition with a strong emphasis on the objective of EU integration, which would, they conclude, largely influence the legal framework and implementation of minority rights in Serbia ${ }^{65}$. After the 2016 elections, MEP became a parliamentary party. They maintained a coalition with VMSZ and VMDP on the national, provincial and local level ${ }^{66}$, while through the VMSZ partnership they remained coalition partners with the leading Serbian party SNS as well ${ }^{67}$.

In 2015, after a series of disagreements with the leadership, two prominent members of VMSZ left the party and founded the Hungarian Movement - a political organisation with the aim of supporting political pluralism, freedom of speech and the democratisation of the Hungarian ethnic group in Serbia. In one of his first interviews, the founder of MM, László Varga stated that Hungarian political entities are neglecting the objective of an autonomous Vojvodina province; the Hungarian National Council (under the command of VMSZ) had no meaningful purpose or objectives in the period prior to Varga's expulsion from $\mathrm{VMSZ}^{68}$, and lastly, there was a lack of tolerance and space for new streams of politics inside $\mathrm{VMSZ}^{69}$. At the first official gathering of MM members, the organisation received the unexpected support of the prominent Hungarians in Serbia, including the former president of the Hungarian National Council (HNC), Tamás Korhecz ${ }^{70}$.

VMSZ remains the only Hungarian party active on the national level, the fragmented opposition in 2018 consisted of five parties which managed to agree only on the insignificance of VMSZ's political agenda regarding the autonomy of Hungarians and Vojvodina province. The lack of focus on autonomy could be somewhat linked to VMSZ's cooperation with SNS at provincial level, representing one of the more "flexible" patterns of policymaking employed by SNS. While a shift in leadership among Hungarian parties in Serbia is unlikely to occur in the immediate future, the rise and fall of small minority 
${ }^{71}$ Horowitz 1992.

${ }^{72}$ Alonso 2007.

${ }^{73}$ Email Interview with Zoltán Szmieskó, the Chairman of MEP, by E.Redžić (2019).

${ }^{74}$ Alonso 2007.

parties attempting to take a share of power at the local level can be expected by observing the past 30 years. Horowitz argued that the inter-group competition in federal states will occur even in the homogenous federal units ${ }^{71}$. The case of VMSZ long-lasting victories among the Hungarian voters goes hand in hand with findings that the existence of smaller, radical minority parties allows the major ethnonationalist one to adopt less extreme stances leading to access to the larger pool of voters ${ }^{72}$. In 2019, Szmieskó stated that the most important objective for the Hungarian minority is to gain proportional representation in the employment in public offices according to minority population shares ${ }^{73}$, though the enduring success of the VMSZ through capitalising on the political fragmentation, and participation in a series of coalition governments, may not provide motivation to seek change. This also fits research which demonstrated that ethnic parties are less harshly judged by economic or governmental performance, thus being less likely to be punished at the ballot box ${ }^{74}$.

This article began by noting the presence of sizable Hungarian minorities and differences between the post-communist experiences of Serbia and Slovakia. The main research question is who these parties are, what they represent and where they came from. Secondly, as they develop, how do they (re)position themselves in the multidimensional space parties occupy? In answering these questions, a summary of party development was provided, before focusing on the stages of party development, namely: party roots and early years, opposition to nationalist governments and finally entering the mainstream but still dogged by conflict. The main findings are that Hungarian minority representation is incredibly fragmented and dogged by conflict in both countries; however, during exceptional times they were able to show a united front to nationalist governments. In more recent times, conflict has returned to the fore, despite attempts to unite being made in Slovakia, especially. Movement towards integration on the continuum, essentially by Most-Híd, represents the main movements in the multidimensional space parties occupy. Other parties, e.g. religious parties, have remained quite consistent with the triadic relational nexus more salient than party repositioning in Serbia.

The extreme fragmentation of Hungarian minority parties in Serbia, even compared to the situation in Slovakia, and the complications which this entails, is perhaps the most notable difference. The 1998 changes to the Slovakian electoral law discouraged further fragmentation, even though there was a split in the main party over a decade later. Serbia on the other hand encouraged fragmentation, purposefully or otherwise, via electoral rules; as the ease of registration and lack of a threshold prior to the 2007 elections had quite the opposite effect. The extreme fragmentation benefited the largest minority party - VMSZ, which managed to maintain its power on all federal levels, along the mainstream Serbian parties and coalitions, and against all attempts from the minority competition.

The similarities, on the other hand, were striking, particularly in the stages of development of the parties in both cases. Firstly, as the dominant communist regime lost its grip on power representation for the Hungarian 
minority sprung forth. Moreover, in both cases a dominant politician was central in both systems and during the 1990s and early 2000s opposition to Mečiar and Milošević was at the forefront of the experiences of ethnic minority parties in both cases. However, after these politicians left the political stage, disgraced to varying degrees, the political experience of Hungarian minority parties somewhat diverged. Both entered the mainstream to an extent, but while Hungarian minority parties in Slovakia were able to join governments, those in Serbia were more focused on the region of Vojvodina and showed much less interest in national level governance.

The need for Hungarian representation in these two countries shows no sign of abating and as such minority parties based on Hungarian ethnicity, language and culture look set to remain. How parties position themselves may well change in the future and further studies may seek to map such changes and explain the motivation behind them. Others might follow the lead of

${ }^{75}$ Székely and Horváth 2014.
References ments which these parties exist within ${ }^{75}$.

A Magyar Koalíció Autonómiakoncepcióját [The Concept of Autonomy of the Hungarian Coalition]. (2008) // URL: https://www.vajma.info/docs/ MK_autonomiakoncepcio_2008_03_17.pdf (accessed on 14.12.2020). (In Hung.)

Alonso S. (2007) Enduring Ethnicity: The Political Survival of Incumbent Ethnic Parties in Western Democracies. Cambridge: Cambridge University Press.

Bárdi N. (2004) Tény És Való: A Budapesti Kormányzatok És a Határon Túli Magyarság Kapcsolattörténete: Problémakatalógus [Fact and Reality: The Contact History of the Budapest Governments and the Hungarians across the Border: Problem Catalog]. Pozsony: Kalligram. (In Hung.)

Bolton J. (2012) Worlds of Dissent: Charter 77, the Plastic People of the Universe, and Czech Culture under Communism. Cambridge (Mass): Harvard University Press.

Brubaker R. (1995) "National Minorities, Nationalizing States, and External National Homelands in the New Europe" // Daedalus, vol. 124, no. 2: 107-132.

Brubaker R. (2002) "Ethnicity without Groups" // European Journal of Sociology / Archives Européennes de Sociologie, vol. 43, no. 2: 163-189.

Bugajski J. (2002) Political Parties of Eastern Europe: A Guide to Politics in the Post-Communist Era. New York: M.E.Sharpe.

Census 2011. (2011) URL: http://www.stat.gov.rs/en-us/oblasti/popis/ popis-2011/ (accessed on 14.12.2020).

Csergo Z. and J.M.Goldgeier. (2004) "Nationalist Strategies and European Integration" // Perspectives on Politics, vol. 2, no. 1: 21-37.

Deegan-Krause K. (2012) "Populism, Democracy, and Nationalism in Slovakia" // Mudde C. and C.Rovira Kaltwasser, eds. Populism in Europe and the Americas: Threat or Corrective for Democracy. New York: Cambridge University Press: 182-204. 
DZVM: SVM Na Mala Vrata Uvodi Miloševićevu Politiku [DZVM: SVM Na Milo Vrata Introduces Milosevic's Policy]. (2015) URL: http://www. vmdk.org.rs/sajtovisszhang/419-dzvm-svm-na-mala-vrata-uvodi-milosevicevupolitiku (accessed on 14.12.2020). (In Serb.)

Gerring J. (2006) Case Study Research: Principles and Practices. New York: Cambridge University Press.

Gluscevic S. (2017) "Kako Nestaje Multinacionalna Vojvodina" [How Multinational Vojvodina Disappears] // Voice, 21.10. URL: http://voice. org.rs/kako-nestaje-multinacionalna-vojvodina/ (accessed on 14.12.2020). (In Serb.)

Goldman M.F. (1999) Slovakia since Independence: A Struggle for Democracy. Westport: Praeger.

Haughton T. (2014) "Exit, Choice and Legacy: Explaining the Patterns of Party Politics in Post-Communist Slovakia" // East European Politics, vol. 30, no. 2: $210-229$.

Hódi S. (1997) Magyar Pártpreferenciák, Politikai Törésvonalak A Vajdasági Magyarság Körében [Hungarian Party Preferences, Political Breakpoints among the Hungarians of Vojvodina]. URL: http://hodis.vmmi. org/delivegeken/LegTer/LT-97.htm (accessed on 14.12.2020). (In Hung.)

Horowitz D.L. (1992) A Democratic South Africa? Constitutional Engineering in a Divided Society. Berkeley: University of California Press.

Horowitz D.L. (1993) "The Challenge of Ethnic Conflict: Democracy in Divided Societies" // Journal of Democracy, vol. 4, no. 4: 18-38.

Howe I., S.Sontag, and K.Vonnegut Jr. (1983) "The Case of Miklos Duray" // The New York Review, 31.03. URL: https://www.nybooks.com/ articles/1983/03/31/the-case-of-miklos-duray/ (accessed on 13.09.2019)

Ifković Z. (2015) "Intervju: László Varga, Osnivač Nevladine Udrugu Mađarski Pokret i Poslanik u Narodnoj Skupštini Srbije” [Interview: László Varga, Founder of the NGO Hungarian Movement and Member of the National Assembly of Serbia] // Hrvatske novine [Croatian Newspaper], 30.11. URL: http://www.hnl.org.rs/nova/iz-srbije/58-politika/590-intervju-laszlovarga-osnivac-nevladine-udrugu-madarski-pokret-i-poslanik-u-narodnojskupstini-srbije (accessed on 14.12.2020). (In Serb.)

Jackson-Preece J. (1997) "Minority Rights in Europe: From Westphalia to Helsinki" // Review of International Studies, vol. 23, no. 1: 75-92.

Jenne E. (2004) "A Bargaining Theory of Minority Demands: Explaining the Dog That Did Not Bite in 1990s Yugoslavia" // International Studies Quarterly, vol. 48, no. 4: 729-754.

Lijphart A. (1971) "Comparative Politics and the Comparative Method" // American Political Science Review, vol. 65, no. 3: 682-693.

"Magyar-Hungarian Forum Party Submits Petition for Registration". (2019) // Visegrad Group, 31.01. URL: http://www.visegradgroup.eu/news/ magyar-hungarian-forum (accessed on 14.12.2020).

Marjanov Е. (2015) "Варга: Неистина да сарађујемо с Јобиком у одбрани Пајтића" [Varga: It Is Not True That We Are Cooperating with Jobik in Pajtićs Defense] // Дневник [Diary], 16.12. URL: https://www. 
dnevnik.rs/politika/varga-neistina-da-saradjujemo-s-jobikom-u-odbrani-pajtica (accessed on 14.12.2020). (In Serb.)

Millard F. (2004) Elections, Parties, and Representation in PostCommunist Europe. Basingstoke: Palgrave Macmillan.

Mirnics K. (2000) "Politikai Önszerveződés" [Political Self-Organization] // Vajdasági Marasztaló (Millenniumi Tanulmánykötet És Címtár) [Vojvodina Judge (Millennium Study Volume and Directory)]. Subotica: The Scientific Association for Hungarology Research: 249-280. (In Hung.)

"Most-Hid, SMK Rule out Merger". (2019) // Visegrad Group, 11.07. URL: http://www.visegradgroup.eu/news/most-hid-smk-rule-out, (accessed on 14.12.2020).

Necin G. (2012) E-Novine.Com - Jobik Podržava Pokret Mađarske Nade [E-Novine.Com - Jobbik Supports the Hungarian Hope Movement]. URL: http://www.e-novine.com/srbija/vesti/61312-Jobik-podrava-Pokretmaarske-nade.html (accessed on 04.08.2019). (In Serb.)

"Osnovana Šesta Vojvođanska Mađarska Stranka" [The Sixth Vojvodina Hungarian Party Was Founded]. (2012) // Rádio-Televizia Vojvodiny [Radio-Television of Vojvodina], 3.05. URL: http://www.rtv.rs/sk/politika/ osnovana-sesta-vojvodjanska-madjarska-stranka_316773.html (accessed on 14.12.2020). (In Serb.)

Petsinis V. (2020) National Identity in Serbia: The Vojvodina and a Multi-Ethnic Community in the Balkans. London: Bloomsbury Academic.

Pettai V. (2006) "Explaining Ethnic Politics in the Baltic States: Reviewing the Triadic Nexus Model" // Journal of Baltic Studies, vol. 37, no. 1: 124-136.

Rosenberger C. (1993) "Independent Slovakia: A New Country's Old Habits" // World Policy Journal, vol. 10, no. 3: 73-80.

Sasse G. (2005) "EU Conditionality and Minority Rights: Translating the Copenhagen Criterion into Policy" // EUI-RSCAS Working Papers, no. 16.

Šimečka M.M. (2020) "Béla Bugár, Bridge Builder" // VoxEurop (English), 29.06. URL: https://voxeurop.eu/en/bela-bugar-bridge-builder/ (accessed on 14.12.2020).

Sulavik C. (1992) "Ethnic Hungarians in Slovakia Hasten to Protect Rights" // Christian Science Monitor, 3.09. URL: https://www.csmonitor. com/1992/0903/03062.html (accessed on 14.12.2020).

Székely I.G. (2014) Dynamics of Party Politics, Electoral Competition and Cooperation within the Hungarian Minorities of Romania, Serbia and Slovakia. Budapest: CEU. URL: http://stage1.ceu.edu/sites/pds.ceu.hu/ files/attachment/basicpage/478/istvanszekely.pdf (accessed on 14.12.2020).

Székely I.G. and I.Horváth. (2014) "Diversity Recognition and Minority Representation in Central and Southeast Europe: A Comparative Analysis" // Nationalities Papers, vol. 42, no. 3: 426-448.

Tanjug. (2013) "Pokret mađarske nade traži teritorijalnu autonomiju po modelu Kosova" [The Hungarian Hope Movement Is Seeking Territorial Autonomy Modelled on Kosovo] // Blic, 16.05. URL: https://www.blic.rs/vesti/ politika/pokret-madarske-nade-trazi-teritorijalnu-autonomiju-po-modelukosova/km3jy03 (accessed on 14.12.2020). (In Serb.) 
Tanjug. (2015) "Laslo Varga: Isključen sam iz SVM jer sam iznosio svoje mišljenje" [Laszlo Varga: I Was Expelled from SVM Because I Expressed My Opinion] // Blic, 18.08. URL: https://www.blic.rs/vesti/politika/laslo-vargaiskljucen-sam-iz-svm-jer-sam-iznosio-svoje-misljenje/rzq6g12 (accessed on 14.12.2020). (In Serb.)

Tarrow S. (2010) "The Strategy of Paired Comparison: Toward a Theory of Practice” // Comparative Political Studies, vol. 43, no. 2: 230-259.

"Three Vojvodinian Hungarian Parties Met in Subotica". (2016) // Vajdaság $m a, 18.01$. URL: https://www.vajma.info/cikk/english/1475/ThreeVojvodinian-Hungarian-Parties-Met-in-Subotica.html (accessed on 14.12.2020).

Tumbas N. (2015) "Formiran Mađarski Pokret Kao Civilna Organizacija" [Hungarian Movement Formed as a Civil Organization] // Subotica, 21.08. URL: https://www.subotica.info/2015/08/21/formiran-madarski-pokretkao-civilna-organizacija-deo-1-0 (accessed on 14.12.2020). (In Serb.)

Vagovič M. (2009) "Mad'arský disent bol o krok vpred" [The Hungarian Dissent Was One Step Ahead] // SME, 21.10. URL: https://domov.sme.sk/c/ 5071427/madarsky-disent-bol-o-krok-vpred.html (accessed on 13.12.2020). (In Slov.)

Vékás J. (1998) “Vajdasági Magyar Eseménynaptár 1988-1997” [Vojvodina Hungarian Calendar of Events 1988-1997] // Regio-Kisebbség, politika, társadalom [Regio-Minority, Politics, Society], no. 2: 151-185. (In Hung.)

Zuber C.I. (2012) "Ethnic Party Competition beyond the Segmented Market” // Nationalities Papers, vol. 40, no. 6: 927-944.

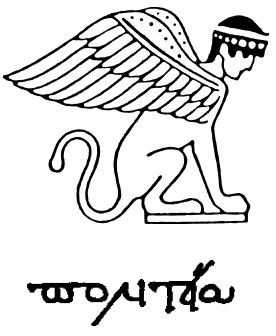

\section{Дж.Эверетт, Э.Реджич В ПОИСКАХ ПРЕДСТАВИТЕЛЬСТВА: РАЗВИТИЕ ПАРТИЙ ВЕНГЕРСКОГО МЕНЬШИНСТВА В СЕРБИИ И СЛОВАКИИ}

Джудас Эверетт - аспирант департамента политики и управления факультета социальных наук Национального исследовательского университета «Высшая школа экономики». Для связи с автором: judas.everett@gmail.com.

Эна Реджич - аспирантка департамента политики и управления факультета социальных наук Национального исследовательского университета «Высшая школа экономики». Для связи с автором: enaredzic1@gmail.com. 
Аннотация. Со времен Трианонского договора 1920 г. в странах, соседствующих с современной Венгрией, проживают значительные венгерские меньшинства. После падения авторитарных коммунистических режимов и перехода к политическому плюрализму венгерское население этих стран начало борьбу за политическое представительство, часто используя в этих целях этнические партии. В статье рассматривается роль этих партий как инструментов представительства венгерского меньшинства в Сербии и Словакии. Обозначено общее развитие таких партий, выявлены этапы их развития и дан подробный анализ каждого из этапов. Проведенное авторами исследование показывает, что претендующие на представительство венгерского меньшинства силы в обеих странах необычайно разрознены и раздираются конфликтами, о чем свидетельствуют, в частности, многочисленные партийные расколы, ликвидация одних партий и образование новых. При всем том в критических обстоятельствах эти силы все же оказывались способны выступить единым фронтом против националистических правительств, примеры чего можно видеть как в Сербии, так и в Словакии. В последнее время, однако, дезинтеграционные тенденции вновь выдвинулись на передний план, хотя ситуация в двух странах не совсем идентична. Если в Сербии конфликт между партиями, объявляющими себя представителями венгерского меньшинства, достиг чрезвычайной остроты и путей разрешения его не просматривается, то в Словакии предпринимались попытки объединения, правда, не увенчавшиеся пока скольконибудь ощутимым успехом.

Ключевые слова: Сербия, Словакия, венгерское меньшинство, политика меньшинств, партийное развитие, посткоммунистический транзит 